\title{
Determinants of Knowledge and Use of Information Communication Technology at Eco-destinations in Old Oyo National Park, Ikogosi Warm Spring Resort and Lacampagne Tropicana in Nigeria
}

\author{
*OYEBODE, A; ADEYEMO, AI; OLADEJI,SO
}

\author{
Department of Ecotourism and wildlife, The Federal University of Technology Akure, Nigeria \\ *Corresponding Author Email: amosoyebode@gmail.com
}

\begin{abstract}
Information Communication Technology has become significant to the development and growth of modern tourism. This study aimed to examine the knowledge and use of information and communication at Old Oyo National Park, Ikogosi Warm Spring Resort and Lacampagne Tropicana by using structured questionnaire directed at fifty percent of the total members of staff at the sites. Data indicated that majority of the staff at Old Oyo National Park (82.9\%), Ikogosi Warm Spring Resort (95\%) and Lacampagne Tropicana (88.9\%) were knowledgeable about the use of information and communication technology especially the use of internet and social media. The staff were also a little competent with the use of Information and Communication Technology at Old Oyo National Park (45.7\%), Ikogosi Warm Spring Resort (50\%) and Lacampagne Tropicana staff (44.4\%). Furthermore, the socio-demographic characteristics of the staff has a significant relationship with their knowledge on the existence of Information Communication Technology at the sites. The management need to organize proper trainings for the staff on the use of Information and Communication Technology so as to improve satisfaction of tourists.
\end{abstract}

DOI: https://dx.doi.org/10.4314/jasem.v25i12.10

Copyright: Copyright (C) 2021 Oyebode et al. This is an open access article distributed under the Creative Commons Attribution License (CCL), which permits unrestricted use, distribution, and reproduction in any medium, provided the original work is properly cited.

Dates: Received: 22 August 2021; Revised: 17 September 2021; Accepted: 06 October 2021

Keywords: Determinants, Demographic, Ecotourism, Hospitality, Technology, Tourism

The swift growth and new modification in Information and Communication Technology (ICT) has caused great improvements in tourism operations and the way firms and nations attract tourists, thereby creating a resultant effect on the serious competition in the tourism industry worldwide (Jacobsen and Munar, 2012). Information Communication Technology has become significant to the development and growth of modern tourism (Molz, 2012). Information Communication Technology has created the enablement of providing new innovative tools for simplifying tourism operations in the aspect of distribution channels, thereby establishing competition in the new tourism business environment (Sigala and Chalkiti, 2014). Globally, there has been a lot of changes over the years and information communication technology has become a focus topic in diverse business firms and organizations. As tourism industry is the foremost industry linked with the progressive nature of information and communication technology, tourist transactions in electronic form have become important in the tourism industry and this has provided high competition in how quality of service is provided in tourism destinations as well as new marketing strategies through the use of information communication technology (Guemide et al., 2019). Tourism destinations that do not provide the mechanism for full adoption of Information Communication Technology might be faced with the challenge of fizzling out of global tourism market (Hoarau and Kline, 2014). Ogbu et al. (2011) studied how Information Communication Technology can provide improvement for operations in the tourism sector in Nigeria. The study illustrated diverse ways by which Information Communication Technology have been adapted in the tourism sector and results revealed that a substantial number of tourism products can be sold online without the consumer visiting the destination prior to making any choice since tourism products are not already produced goods. Booking of flights and hotel reservations can be accomplished online through e-mail, telephone calls as well as other internet services thereby reducing if not eradicating completely the elongated process of the old system. Toumi and Kherif (2011) opined that online marketing for tourism has been highly important, specifically with the massive growth and development in modern technologies and the improved usage of the Internet. Since it is fast emerging the most competitive aspect 
in the tourism marketing environment, the researchers demonstrated the importance of the fact that tourism destinations must improve their competitiveness by incorporating modern sources and innovations in news transmission to their consumers in order to ensure provision of standard quality of services to improve customer satisfaction. These studies have proven the importance of Information Communication Technology in tourism destinations but there has been dearth of information on the knowledge and use of Information and Communication Technology at tourism destinations in Nigeria which this study aimed to find out.

\section{MATERIALS AND METHODS}

This study was carried out at Old Oyo National Park managed by the Federal Government of Nigeria located within coordinates $7.850171^{\circ} \mathrm{N}$ and $3.911465^{\circ} \mathrm{E}$, Ikogosi Warm Spring managed by Ekiti State government located within coordinates $7.590804^{\circ} \mathrm{N}$ and $4.980059^{\circ} \mathrm{E}$ and Lacampagne Tropicana managed privately located within coordinates $6.3926^{\circ} \mathrm{N}$ and $4.1865^{\circ} \mathrm{E}$.

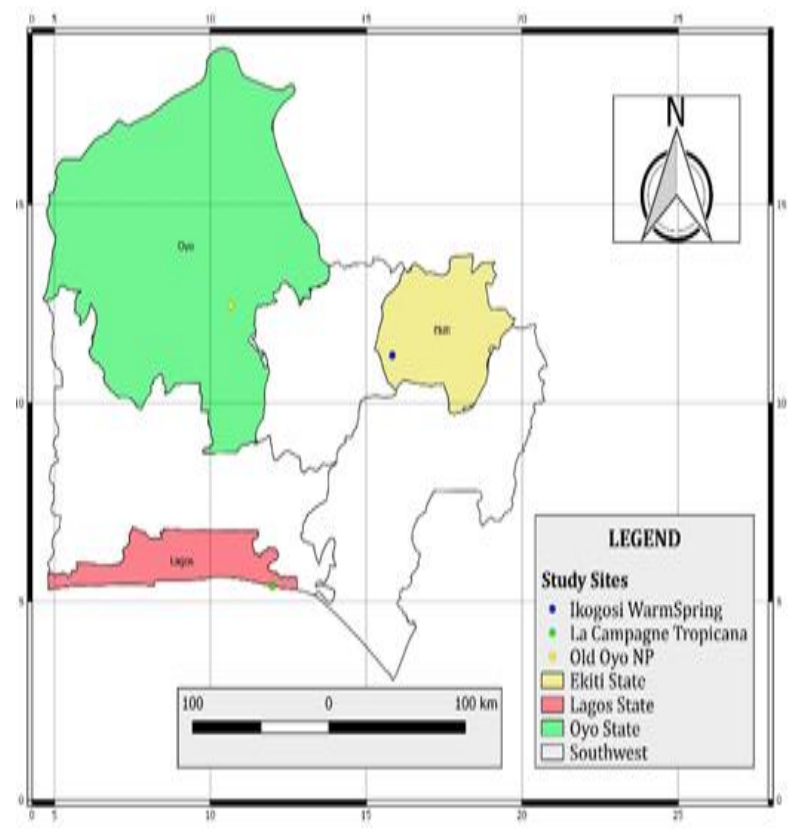

Fig 1: Map of Southwest Nigeria showing the study areas Source: Authors' Field Survey, 2021

The target population for this study were staff of the sites and fifty percent of the staff were randomly chosen to fill a well-structured questionnaire targeted at capturing socio-demographic characteristics of the staff as well as their usage of information Communication Technology. This study made use of relevant literatures to construct questions in the questionnaire. Data was obtained across the three sites from January to June, 2021. Data was collated and analyzed using Statistical Package for Social Science version 23 and results were presented descriptively using frequency, percentage and tables. Inferentially, binary logistic regression was used to analyze the determinants of knowledge of the existence of Information Communication Technology at the sites.

\section{RESULTS AND DISCUSSION}

Socio-demographic Characteristics of Staff: Table 1 reveals the socio-demographic characteristics of the members of staff at Old Oyo National Park, Ikogosi Warm Spring Resort and Lacampagne Tropicana. At Old Oyo National Park, majority of the staff were male $(65.7 \%)$, between the ages of $31-40$ years (40\%), married (82.9\%) with tertiary education (94.3\%). Highest percentage of the staff have income range of 丹80,000- $\$ 99,999$ (65.7\%), were Christians (62.9\%) and have spent less than 10 years at the site $(54.3 \%)$. At Ikogosi Warm Spring Resort, there was a gender balance of males and females (50\% each) between the ages of $31-50$ years $(70 \%)$, married $(80 \%)$ with tertiary education $(65 \%)$.

Highest percentage of the staff have income range of 20,000- $\$ 39,999$ (55\%), were Christians (55\%) and all of them have spent less than 10 years at the site (100\%). At Lacampagne Tropicana, majority of the staff were males $(70.4 \%)$, between the ages of 20-30 years $(66.7 \%)$, singles $(74.1 \%)$ with tertiary education $(77.8 \%)$. Also, highest percentage of the staff have income range of $\$ 40,000$ - $\$ 59,999$ (44.4\%), were Christians $(88.9 \%)$ and have spent less than ten years at the site $(96.3 \%)$.

Knowledge and level of competence in information communication technology (ICT): Table 2 reveals that majority of the staff know about ICT existence at Old Oyo National Park (82.9\%), Ikogosi Warm Spring Resort (95\%) and Lacampagne Tropicana (88.9\%). At Old Oyo National Park, majority of the staff are familiar with the use of internet $(80 \%)$ and social media (74.3\%). At Ikogosi Warm Spring Resort, majority of the staff are familiar with the use of social media $(75 \%)$ while majority of the staff are also are familiar with use of social media at Lacampagne Tropicana $(85.2 \%)$. Figure 2 reveals that majority of the Old Oyo National Park staff are a little competent with ICT applications (45.7\%), majority of Ikogosi Warm Spring Resort staff are a little competent with ICT applications (50\%) while majority of Lacampagne Tropicana staff are somewhat competent with ICT applications (44.4\%).

Relationship between tourists' socio-demographic characteristics and their knowledge of the existence of 
ICT: A binary logistic regression was performed to obtain the determinants of knowledge of ICT applications at the site using the tourists' sociodemographic characteristics as the predictor variables (table 3).

The logistic regression model was statistically significant with chi square value of $\chi^{2}=62.503$, $\mathrm{p}<0.05$. The model explained $20.1 \%$ (Nagelkerke R square) of the variance in knowledge of ICT applications at the sites. The final model fit at $62.2 \%$ showed that the socio-demographic characteristics of the tourists had significant relationship with their knowledge of ICT application at the sites. Gender $(\mathrm{P}<0.01)$, occupation $(\mathrm{P}<0.01)$, education $(\mathrm{P}<0.01)$ had significant relationship with knowledge of ICT applications at the sites.

Table 1: Socio-demographic characteristics of the staff

\begin{tabular}{|c|c|c|c|c|c|c|}
\hline \multirow[t]{2}{*}{ Variables } & \multicolumn{2}{|c|}{ Old Oyo National park } & \multicolumn{2}{|c|}{$\begin{array}{l}\text { Ikogosi Warm Spring } \\
\text { Resort }\end{array}$} & \multicolumn{2}{|c|}{ Lacampagne Tropicana } \\
\hline & $\begin{array}{l}\text { Frequency } \\
(35)\end{array}$ & $\begin{array}{l}\text { Percentage } \\
(\%)\end{array}$ & $\begin{array}{l}\text { Frequency } \\
(20)\end{array}$ & $\begin{array}{l}\text { Percentage } \\
(\%)\end{array}$ & $\begin{array}{l}\text { Frequency } \\
(27)\end{array}$ & $\begin{array}{l}\text { Percentage } \\
(\%)\end{array}$ \\
\hline \multicolumn{7}{|l|}{ Sex } \\
\hline Male & 23 & 65.7 & 10 & 50.0 & 19 & 70.4 \\
\hline Female & 12 & 34.3 & 10 & 50.0 & 8 & 29.6 \\
\hline \multicolumn{7}{|l|}{ Age (years) } \\
\hline Below 20 & 1 & 2.9 & 0 & 0 & 1 & 3.7 \\
\hline $20-30$ & 5 & 14.3 & 6 & 30.0 & 18 & 66.7 \\
\hline $31-40$ & 14 & 40.0 & 7 & 35.0 & 5 & 18.5 \\
\hline $41-50$ & 12 & 34.3 & 7 & 35.0 & 3 & 11.1 \\
\hline $51-60$ & 3 & 8.6 & 0 & 0 & 0 & 0 \\
\hline \multicolumn{7}{|l|}{ Marital status } \\
\hline Single & 6 & 17.1 & 4 & 20.0 & 20 & 74.1 \\
\hline Married & 29 & 82.9 & 16 & 80.0 & 7 & 25.9 \\
\hline \multicolumn{7}{|l|}{ Education } \\
\hline Primary & 0 & 0 & 0 & 0 & 1 & 3.7 \\
\hline Secondary & 2 & 5.7 & 7 & 35.0 & 5 & 18.5 \\
\hline Tertiary & 33 & 94.3 & 13 & 65.0 & 21 & 77.8 \\
\hline \multicolumn{7}{|l|}{ Income } \\
\hline 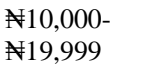 & 0 & 0 & 4 & 20.0 & 2 & 7.4 \\
\hline 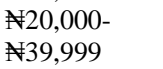 & 4 & 11.4 & 11 & 55.0 & 6 & 22.2 \\
\hline $\begin{array}{l}¥ 40,000- \\
¥ 59,999\end{array}$ & 2 & 5.7 & 3 & 15.0 & 12 & 44.4 \\
\hline 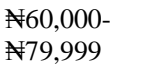 & 6 & 17.1 & 2 & 10.0 & 4 & 14.8 \\
\hline $\begin{array}{l}\$ 80,000- \\
\$ 99,999\end{array}$ & 23 & 65.7 & 0 & 0 & 1 & 3.7 \\
\hline $\begin{array}{l}\text { Above } \\
\$ 100,000\end{array}$ & 0 & 0 & 0 & 0 & 2 & 7.4 \\
\hline Religion & & & & & & \\
\hline Christianity & 22 & 62.9 & 11 & 55.0 & 24 & 88.9 \\
\hline Islam & 13 & 37.1 & 9 & 45.0 & 3 & 11.1 \\
\hline Years spent $v$ & stablishmen & & & & & \\
\hline $\begin{array}{l}\text { Less than } 10 \\
\text { years }\end{array}$ & 19 & 54.3 & 20 & 100.0 & 26 & 96.3 \\
\hline $\begin{array}{l}\text { More than } 10 \\
\text { years }\end{array}$ & 16 & 45.7 & 0 & 0 & 1 & 3.7 \\
\hline
\end{tabular}

Source: Field Survey, 2021 

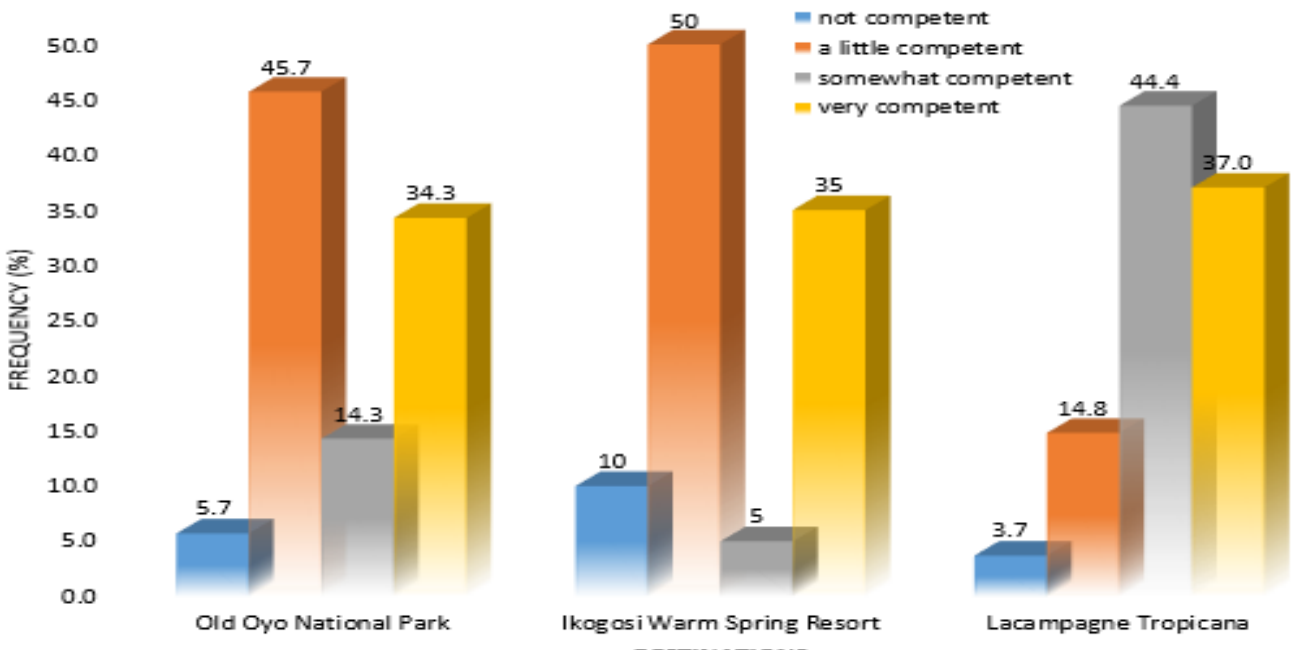

Fig 2: Level of competence with ICT applications at the sites

Table 2: Knowledge of ICT application at the sites

\begin{tabular}{|c|c|c|c|c|c|c|}
\hline \multirow[t]{2}{*}{ Variables } & \multicolumn{2}{|c|}{ Old Oyo National park } & \multicolumn{2}{|c|}{$\begin{array}{l}\text { Ikogosi Warm Spring } \\
\text { Resort }\end{array}$} & \multicolumn{2}{|c|}{ Lacampagne Tropicana } \\
\hline & $\begin{array}{l}\text { Frequency } \\
\text { (35) }\end{array}$ & $\begin{array}{l}\text { Percentage } \\
(\%)\end{array}$ & $\begin{array}{l}\text { Resort } \\
\text { Frequency } \\
\text { (20) }\end{array}$ & $\begin{array}{l}\text { Percentage } \\
(\%)\end{array}$ & $\begin{array}{l}\text { Frequency } \\
\text { (27) }\end{array}$ & $\begin{array}{l}\text { Percentage } \\
(\%)\end{array}$ \\
\hline \multicolumn{7}{|c|}{ Do you know about the existence of ICT in this site? } \\
\hline No & 6 & 17.1 & 1 & 5.0 & 3 & 11.1 \\
\hline Yes & 29 & 82.9 & 19 & 95.0 & 24 & 88.9 \\
\hline \multicolumn{7}{|c|}{ Are you familiar with the use of Geographical Information System? } \\
\hline No & 17 & 48.6 & 8 & 40.0 & 19 & 70.4 \\
\hline Yes & 18 & 51.4 & 12 & 60.0 & 8 & 29.6 \\
\hline \multicolumn{7}{|c|}{ Are you familiar with the use of computer simulation? } \\
\hline No & 21 & 60.0 & 10 & 50.0 & 9 & 33.3 \\
\hline Yes & 14 & 40.0 & 10 & 50.0 & 18 & 66.7 \\
\hline \multicolumn{7}{|c|}{ Are you familiar with the use of Tourism Information System? } \\
\hline No & 19 & 54.3 & 6 & 30.0 & 7 & 25.9 \\
\hline Yes & 16 & 45.7 & 14 & 70.0 & 20 & 74.1 \\
\hline \multicolumn{7}{|c|}{ Are you familiar with the use of Destination Management System? } \\
\hline No & 25 & 71.4 & 12 & 60.0 & 20 & 74.1 \\
\hline Yes & 10 & 28.6 & 8 & 40.0 & 7 & 25.9 \\
\hline \multicolumn{7}{|c|}{ Are you familiar with the use of Environment Management Information System? } \\
\hline No & 22 & 62.9 & 11 & 55.0 & 11 & 40.7 \\
\hline Yes & 13 & 37.1 & 9 & 45.0 & 16 & 59.3 \\
\hline \multicolumn{7}{|c|}{ Are you familiar with the use of Economic Impact Analysis Software? } \\
\hline No & 31 & 88.6 & 10 & 50.0 & 18 & 66.7 \\
\hline Yes & 4 & 11.4 & 10 & 50.0 & 9 & 33.3 \\
\hline \multicolumn{7}{|c|}{ Are you familiar with the use of Virtual Tourism? } \\
\hline No & 22 & 62.9 & 8 & 40.0 & 11 & 40.7 \\
\hline Yes & 13 & 37.1 & 12 & 60.0 & 16 & 59.3 \\
\hline \multicolumn{7}{|c|}{ Are you familiar with the use of Location-based services? } \\
\hline No & 25 & 71.4 & 12 & 60.0 & 14 & 51.9 \\
\hline Yes & 10 & 28.6 & 8 & 40.0 & 13 & 48.1 \\
\hline \multicolumn{7}{|c|}{ Are you familiar with the use of e-rating system? } \\
\hline No & 29 & 82.9 & 13 & 65.0 & 20 & 74.1 \\
\hline Yes & 6 & 17.1 & 7 & 35.0 & 7 & 25.9 \\
\hline \multicolumn{7}{|c|}{ Are you familiar with the use of internet? } \\
\hline No & 7 & 20.0 & 6 & 30.0 & 5 & 18.5 \\
\hline Yes & 28 & 80.0 & 14 & 70.0 & 22 & 81.5 \\
\hline \multicolumn{7}{|c|}{ Are you familiar with the use of social media? } \\
\hline No & 9 & 25.7 & 5 & 25.0 & 4 & 14.8 \\
\hline Yes & 26 & 74.3 & 15 & 75.0 & 23 & 85.2 \\
\hline \multicolumn{7}{|c|}{ Are you familiar with the use of Carbon Calculators? } \\
\hline No & 29 & 82.9 & 11 & 55.0 & 20 & 74.1 \\
\hline Yes & 6 & 17.1 & 9 & 45.0 & 7 & 25.9 \\
\hline
\end{tabular}


Table 3: Relationship between tourists' socio-demographic characteristics and their knowledge of the existence of ICT at the

\begin{tabular}{llllll}
\multicolumn{5}{c}{ sites } \\
\hline Variables & B & S.E. & Wald & Sig. & $\operatorname{Exp}(\mathbf{B})$ \\
\hline Gender & 1.366 & .265 & 26.655 & .000 & 3.920 \\
Age & .148 & .229 & .421 & .517 & 1.160 \\
Marital status & .518 & .382 & 1.835 & .176 & 1.678 \\
Occupation & .403 & .137 & 8.696 & .003 & 1.497 \\
Education & .796 & .238 & 11.204 & .001 & 2.217 \\
Income & -.129 & .072 & 3.224 & .073 .879 \\
Religion & -.498 & .316 & 2.494 & .114 .608 \\
Constant & -7.121 & 1.615 & 19.440 & .000 .001 \\
Correct prediction: $62.2 \% ;$ Final model fit -2 log likelihood: \\
\multicolumn{4}{c}{ 468.072; Nagelkerke R Square: 0.201}
\end{tabular}

The staff had a close mixture of males and females at the sites and they were mostly within the youthful ages of 20-50 years. This is inconsistent with study by UNWTO (2011) which revealed that despite developing and improving tourism industry opportunities by numbers, and the obvious "diversity merit" this brings, women are continually underrepresented in senior and general management positions and when it comes to women in leadership roles, the tourism sector falls short of other industries that don't demonstrate similar benefit. Majority of the staff were married at both Old Oyo National Park and Ikogosi Warm Spring Resort while majority of the staff were single at Lacampagne Tropicana. The staff income at Old Oyo National Park is relatively higher than the staff income at Ikogosi Warm Spring and Lacampagne Tropicana which could be due to the fact that Old Oyo National Park is a federal establishment. Most of the staff were Christians and have spent less than ten years with the sites. The staff know affirmed the existence of Information Technology applications such as Geographical Information System, environmental management information system, destination management system at the sites as supported by Eraqi (2014) that ICT in tourism sector consists of many components that include computerized reservation systems, teleconferencing, videos, video brochures, management information systems, airline electronic information systems, electronic funds transfer, digital telephone networks, smart cards, mobile communication, e-mail, and internet. The staff are a little competent with the information communication technology applications which could be as a result of inadequate training of staff. Staff need to be properly trained about operations of Information Communication Technology applications as they might be complex and technical to use as opined by Opara and Onyije (2013) who emphasized that Information Communication Technologies include 'electronic networks - embodying complex hardware and software - linked by a vast array of technical protocols. Internet and social media are the major Information Communication Technology applications they use at the sites implying that these destinations need to diversify into other Information Technology Applications so as to fully explore the technology world for effective and efficient operations as supported by Chandler and Munday (2011) who shared a concept that information and communication technology is an umbrella term for all of the various media employed in communicating information, e.g. computers, the Internet, television broadcast and even printed and handwritten notes.

Conclusion: This study concludes that the staff are knowledgeable about Information Communication application at the sites with social media and internet reported to have the highest usage. The staff are a little competent with the information communication technology applications which could be as a result of inadequate training of staff. Management of ecotourism sites should devote resources towards acquiring and using more information communication technology applications in order to improve sustainability of these sites and be up to date with other sites all over the world.

\section{REFERENCE}

Chandler, D; Munday, R (2011). Oxford dictionary of media and communication. New York: Oxford University Press.

Eraqi, MI (2014). ICTs as a co-creative way for effective tourism strategic marketing in Egypt. Inter. J. Tourism Anthropology, 3(4), 370-393.

Guemide B; Benachaiba C; Maouche S (2019) Integrating ICT- Based Applications for Sustainable Tourism Development in Algeria. $J$ Tourism Hospit 8:415.

Hoarau, H; Kline, C (2014). Science and industry: Sharing knowledge for innovation. Annals of Tourism Research, 46, 44-61.

Jacobsen, JKS; Munar, AM (2012). Tourist information search and destination choice in a digital age. Tourism Manage. Persp., 1, 39-47.

Ogbu S; Idris S; Ijagbemi AB (2011). Information and communication technology (ICT): A veritable tool for tourism development in Nigeria. In Nigeria Computer Society (NCS): 10th International Conference.;25-29.

Opara, JA; Onyije, E (2013). Information and communication technologies (ICT): a panacea to achieving effective goals in institutional administration. Inter. J. Manage. Sci. 1 (1): 11-15. 
Molz, JG (2012). Travel connections: Tourism, technology, and togetherness in a mobile world: Routledge.

Sigala, M; Chalkiti, K (2014). Investigating the exploitation of web 2.0 for knowledge management in the Greek tourism industry: An utilisation-importance analysis. Computers in Human Behavior, 30, 800-812.
Toumi M; Kherif N (2011). The role of e-tourism in promoting tourism industry. The Economics of Tourism and Sustainable Development; 9-10.

UNWTO (2011). Tourism Highlights 2011 Edition. Retrieved on 12/ 03/2015 http://mkt.unwto.org/sites/all/files/docpdf/u nwtohighlights11enhr.pdf 